\title{
Sugarcane Production for 12-, 18-, and 24-Month Cycles Under Conditions in Puerto Rico
}

\author{
S. Alers-Alers, M. A. Lugo-López, and R. Gandıa Caro' \\ INTRODUCTION
}

Sugarcane production in Puerto Rico follows the conventional cropping pattern of spring and fall cycles in which plant canes develop for 10 to 12 and 16 to 18 or 20 months, respectively, before harvesting. Subsequent ratoon crops are harvested approximately every 12 months. Cropping practices differ in other sugarcane producing areas. In Hawaii, for instance, the bulk of the sugarcane crop consists of 24-month cane.

The sugarcane industry of Puerto Rico has been undergoing a highly critical period for a number of years, primarily because of low yields. The Agricultural Experiment Station of the University of Puerto Rico has been conducting an intense research effort to help remedy this serious situation. One of the major current research programs concerns the development and evaluation of new, more productive, varieties of sugarcane tailored to specific conditions. Top research priority also has been given the feasability of mechanical harvesting under the particular conditions prevailing in Puerto Rico. Our experience to date, however, suggests that improved management of soils and the crops grown thereon also are necessary to attain substantial improvement in yields. Studies thus have been undertaken concerning crop and soil factors affecting sugarcane production. This paper reports evaluation of 12-, 18-, and 24-month cropping cycles under Puerto Rican conditions.

\section{MATERIALS AND METHODS}

Two field experiments were established, one at Barceloneta in an area of alluvial soils of the Toa series in the north coast, and one at Corozal on terraces of a Lares clay soil in the hilly section of north-central Puerto Rico. The experiments at both locations followed a split plot design with six replications. The plots were 20 by 24 feet. Six varieties were included in the experiments (P.R. 1028, P.R. 1016, P.R. 1013, P.R. 980, P.R. 975 and B. 4362) and these were harvested at the three ages of 12-, 18- and 24months. Three-eyed seed pieces were planted in rows five feet apart for a total of 12,000 seed pieces to the acre. The 18-month cane was planted in October 1959; the 12- and 24-month canes were planted in March, 1960.

${ }^{1}$ Assistant Agronomist, Soil Scientist and Associate Agronomist, respectively, Agricultural Experiment Station, Mayagüez Campus, University of Puerto Rico, Rio Piedras and Isabela, P.R. 
All plots received a 14-4-10 fertilizer at the rates of 8,10 and 14 hundredweights to the acre for the 12-, 18- and 24-month canes, respectively. For the 12- and 18-month cane, all the fertilizer was applied at planting time; for the 24-month old cane, the fertilizer was split into two applications, one-half at time of planting and one-half when the cane was 12 months old. Land preparation and cultivation practices followed the routine for the respective area. The cane from each plot was weighed at harvest and a 20-cane sample from each plot was taken to determine sucrose percent cane. Based on tonnage and sucrose yields, sugar yields per acre were calculated, as well as tons of cane per acre per month and tons of sugar per acre per month. Combined yields for all crop yields were calculated at the end of the crop cycles.

At Barceloneta, in a period of 48 months, one plant crop and three ratoon crops were harvested in the case of spring cane (12-month cycle); in a period of 42 months, one plant crop and two 12-month ratoon crops were harvested for the fall cane (18-month cycle); and again, in a period of 48 months, one plant crop and one ratoon crop were harvested for the Hawaiian (24-month) cycle. The experiment conducted at Corozal was identical except for the spring cane cycle in which only one plant crop and two ratoon crops were harvested for a total of 36 months of cropping.

\section{RESULTS AND DISCUSSION}

Summarized data on mean production in terms of tons of cane per acre, tons of cane per acre per month, sucrose percent cane, tons of sugar per acre and tons of sugar per acre per month are given in table 1 for each cropping cycle, both at Corozal and Barceloneta. This table summarizes all data without regard to differences between varieties.

There were no significant differences at Corozal between means as far as tons of cane per acre was concerned. However, the 12- and 18-month cane were more efficient producers than the 24-month cane. Mean differences between the first two and the latter were highly significant when data on tons of cane per acre per month were considered as a criterion. At Barceloneta, both 18- and 24-month cane produced significantly more tons of cane per acre than 12-month cane. However, the mean difference between tons of cane per acre per month for 12- and 18-month canes and the 24-month cane again were highly significant, the two former producing the best yields.

The mean differences as to sucrose percent cane were significant at both Corozal and Barceloneta. Higher sucrose was obtained for the 24-month cane. When tons of sugar per acre was taken as the criterion to evaluate the treatments, no significant differences were found at Corozal, while at Barceloneta the yields of the 24-month canes were better at the 1-percent level than those of 12- and 18-month canes. In terms of tons of sugar per acre 
TABLw 1.-Mean production for indicated indices at two locations for each of three cropping cycles

\begin{tabular}{|c|c|c|c|}
\hline \multirow{2}{*}{ Item } & \multicolumn{3}{|c|}{ Yields for indicated cropping cycles 1} \\
\hline & 12-month & 18-month & 24-month \\
\hline \multicolumn{4}{|c|}{ Corozal } \\
\hline $\begin{array}{l}\text { Mean tons of cane per acre per crop } \\
\text { Tons of cane per acre per month } \\
\text { Sucrose percent cane } \\
\text { Tons of sugar per acre } \\
\text { Tons of sugar per acre per month }\end{array}$ & $\begin{array}{r}58.67 \\
4.88 \\
12.64 \\
7.34 \\
.61\end{array}$ & $\begin{array}{r}61.40 \\
4.27 \\
12.77 \\
7.78 \\
.55\end{array}$ & $\begin{array}{r}58.33 \\
2.42 \\
13.09 \\
7.61 \\
.31\end{array}$ \\
\hline \multicolumn{4}{|c|}{ Barceloneta } \\
\hline $\begin{array}{l}\text { Mean tons of cane per acre per crop } \\
\text { Tons of cane per acre per month } \\
\text { Sucrose percent cane } \\
\text { Tons of sugar per acre } \\
\text { Tons of sugar per acre per month }\end{array}$ & $\begin{array}{r}63.22 \\
5.26 \\
11.13 \\
6.95 \\
.57\end{array}$ & $\begin{array}{r}74.77 \\
5.38 \\
11.43 \\
8.46 \\
.61\end{array}$ & $\begin{array}{r}82.63 \\
3.43 \\
12.33 \\
10.13 \\
.42\end{array}$ \\
\hline
\end{tabular}

1 For Corozal, the cropping cycles extended for 36, 42, and 48 months, respectively, in each case. For Barceloneta, they extended for 48,42 , and 48 months, respectively.

TABLe 2.-Total tons of cane per acre obtained from each variety for each of three cropping cycles at two locations

\begin{tabular}{l|r|r|r|r|r|r}
\hline \multirow{2}{*}{ Crop cycle } & \multicolumn{7}{c}{ Yields of indicated variety } \\
\cline { 2 - 6 } & P.R. 1028 & P.R. 1016 & P.R. 1013 & P.R. 980 & P.R. 975 & B. 4362 \\
\hline \multicolumn{7}{c}{ Corozal } \\
\hline 12-month & 153.5 & 131.4 & 167.8 & 208.0 & 207.4 & 188.2 \\
18-month & 145.5 & 161.1 & 192.6 & 210.5 & 208.7 & 187.0 \\
24-month & 114.2 & 92.1 & 130.9 & 134.1 & 134.9 & 98.8 \\
\hline & \multicolumn{7}{c}{ Barceloneta } \\
\hline 12-month & 261.5 & 202.4 & 277.8 & 307.6 & 249.2 & 219.1 \\
18-month & 237.8 & 198.3 & 218.9 & 260.6 & 212.2 & 218.3 \\
24-month & 200.3 & 104.6 & 172.1 & 210.5 & 164.0 & 140.1 \\
\hline
\end{tabular}

per month the mean differences between the 12- and 18-month canes and the 24-month cane were highly significant, the latter being the lowest.

Barceloneta seems to be a better cane producing region for all three cropping cycles when tons of cane per acre and tons of cane per acre per 
month are considered as criteria. However, as far as sucrose percent cane is concerned, yields were consistantly higher at Corozal than at Barceloneta. This can be attributed perhaps to the higher elevation with cooler nights at Corozal $(s)^{2}$ and the more marked differences between maximum and mini-

TABLE 3.-Mean tons of cane per acre per month obtained from each variety for each of three cropping cycles at two locations

\begin{tabular}{l|c|c|c|c|c|c}
\hline \multirow{2}{*}{ Crop cycle } & \multicolumn{6}{c}{ Yields of indicated variety } \\
\cline { 2 - 7 } & P.R. 1028 & P.R. 1016 & P.R. 1013 & P.R. 980 & P.R. 975 & B. 4362 \\
\hline \multicolumn{6}{c}{ Corozal } \\
\hline 12-month & 4.3 & 3.6 & 4.7 & 5.8 & 5.8 & 5.2 \\
18-month & 3.4 & 3.8 & 4.4 & 4.9 & 4.9 & 4.3 \\
24-month & 2.4 & 1.9 & 2.7 & 2.8 & 2.8 & 1.9 \\
\hline & & \multicolumn{7}{c}{ Barceloneta } \\
\hline 12-month & 5.4 & 4.2 & 5.8 & 6.4 & 5.2 & 4.6 \\
18-month & 5.8 & 4.7 & 5.3 & 6.2 & 5.2 & 5.1 \\
24-month & 4.2 & 2.2 & 3.6 & 4.4 & 3.4 & 2.8 \\
\hline
\end{tabular}

TABLE 4.-Sucrose-percent-cane obtained from each variety for each of three cropping cycles at two locations

\begin{tabular}{l|c|c|c|c|c|c}
\hline \multirow{2}{*}{ Crop cycle } & \multicolumn{6}{c}{ Yieldy of indicated variety } \\
\cline { 2 - 6 } & P.R. 1028 & P.R. 1016 & P.R. 1013 & P.R. 980 & P.R. 975 & B. 4362 \\
\hline \multicolumn{7}{c}{ Corozal } \\
\hline 12-month & 12.6 & 13.1 & 12.7 & 11.7 & 12.6 & 13.2 \\
18-month & 12.6 & 13.2 & 12.9 & 12.1 & 13.1 & 13.0 \\
24-month & 12.7 & 13.6 & 13.3 & 12.4 & 13.5 & 13.2 \\
\hline & \multicolumn{7}{c}{ Barceloneta } \\
\hline 12-month & 11.2 & 11.2 & 11.3 & 10.3 & 11.2 & 11.9 \\
18-month & 11.8 & 11.5 & 11.2 & 9.8 & 12.0 & 12.4 \\
24-month & 12.3 & 12.9 & 12.6 & 10.9 & 12.5 & 12.9 \\
\hline
\end{tabular}

I Standard error of the means was rather large.

mum temperature that prevail at Corozal at critical times for the sugarcane crop as compared to Barceloneta. Such conditions, as pointed out by LugoLópez and Capo (4), are conducive to higher sucrose accumulation. For the

${ }^{2}$ Numbers in parentheses refer to Literature Cited, p. 126-7. 
12-month crop cycles sugar production per acre per month seems to be slightly higher at Corozal. The opposite, however, is true for the longer 18and 24-month crop cycles.

Tables 2 and 3 present individual variety data on tons of cane per acre

TABLE 5.-Total tons of sugar per acre obtained from each variety for each of three cropping cycles at two locations

\begin{tabular}{l|c|c|c|c|c|c}
\hline \multirow{2}{*}{ Crop Cycle } & \multicolumn{6}{c}{ Yields of indicated variety } \\
\cline { 2 - 7 } & P.R. 1028 & P.R. 1016 & P.R. 1013 & P.R. 980 & P.R. 975 & B. 4362 \\
\hline \multicolumn{6}{c}{ Corozal } \\
\hline 12-month & 19.2 & 17.1 & 21.2 & 24.0 & 26.0 & 24.7 \\
18-month & 18.1 & 21.1 & 24.2 & 25.2 & 27.2 & 24.6 \\
24-month & 14.5 & 12.5 & 17.4 & 16.6 & 18.1 & 12.3 \\
\hline & \multicolumn{6}{c}{ Barceloneta } \\
\hline 12-month & 29.1 & 22.6 & 30.6 & 31.5 & 27.5 & 25.8 \\
18-month & 27.7 & 22.8 & 24.6 & 25.2 & 25.5 & 26.6 \\
24-month & 24.8 & 13.6 & 21.6 & 22.9 & 20.5 & 18.2 \\
\hline
\end{tabular}

TABLE 6.-Means tons of sugar per acre per month obtained from each variety for each of three cropping cycle at two locations

\begin{tabular}{l|r|r|r|r|r|r}
\hline \multirow{2}{*}{ Crop cycle } & \multicolumn{6}{c}{ Yields of indicated variety } \\
\cline { 2 - 7 } & P.R. 1028 & P.R. 1016 & P.R. 1013 & P.R. 980 & P.R. 975 & B. 4362 \\
\hline \multicolumn{7}{c}{ Corozal } \\
\hline 12-month & 0.53 & 0.48 & 0.59 & 0.67 & 0.72 & 0.68 \\
18-month & .42 & .59 & .56 & .69 & .63 & .56 \\
24-month & .30 & .26 & .36 & .34 & .38 & .26 \\
\hline & \multicolumn{7}{c}{ Barceloneta } & & & \\
\hline 12-month & 0.61 & 0.47 & 0.64 & 0.66 & 0.57 & 0.54 \\
18-month & .68 & .54 & .61 & .61 & .62 & .63 \\
24-month & .52 & .28 & .45 & .48 & .43 & .38 \\
\hline
\end{tabular}

and tons of cane per acre per month at both Corozal and Barceloneta. At Corozal, for the 12-month crop cycle, varieties P.R. 980 and P.R. 975 outyielded varieties P.R. 1016, P.R. 1028 and P.R. 1013 at the 1-percent level; B. 4362 outyielded P.R. 1016 and P.R. 1028; P.R. 1013 and P.R. 1028 outyielded P.R. 1016. At the 5-percent level, P.R. 980 and P.R. 975 were better 
TABLE 7.-Tons of cane per acre obtained from each crop for each of the three cropping cycles at Corozal

\begin{tabular}{|c|c|c|c|c|c|c|}
\hline \multirow{2}{*}{ Crop cycle } & \multicolumn{6}{|c|}{ Yields for indicated variety } \\
\hline & P.R. 1028 & P.R. 1016 & P.R. 1013 & P.R. 980 & P.R. 975 & B. 4362 \\
\hline \multicolumn{7}{|l|}{ 12-month } \\
\hline Plant crop & 66.3 & $\mathbf{5 5 . 0}$ & 73.5 & 88.9 & 94.2 & 82.3 \\
\hline First ratoon 2 & 39.9 & 35.2 & 42.6 & 58.6 & 53.2 & 49.5 \\
\hline Second ratoon ${ }^{8}$ & 47.3 & 41.2 & 51.7 & 60.5 & 60.0 & 50.2 \\
\hline \multicolumn{7}{|l|}{ 18-month } \\
\hline Plant crop & 69.5 & 78.3 & 96.7 & 103.3 & 105.8 & 97.7 \\
\hline First ratoon ${ }^{5}$ & 36.5 & 38.5 & 43.9 & 50.4 & 48.9 & 45.0 \\
\hline Second ratoon ${ }^{\circ}$ & 39.5 & 44.3 & 52.0 & 56.8 & 54.0 & 44.3 \\
\hline \multicolumn{7}{|l|}{ 24-month } \\
\hline Plant crop 7 & 60.5 & 46.8 & 67.4 & 63.9 & 67.9 & 56.5 \\
\hline First ratoon 8 & 53.7 & 45.3 & 63.5 & 70.2 & 67.0 & 37.3 \\
\hline
\end{tabular}

${ }^{1}$ At the 1-percent level, P.R. 975 better than P.R. 1028, P.R. 1016 and P.R. 1013; P.R. 980 better than P.R. 1016 and P.R. 1028; B. 4362 and P.R. 1013 better than P.R. 1016. At the 5-percent level, P.R. 980 better than P.R. 1013; B. 4362 better than P.R. 1028.

2 At the 1-percent level, P.R. 980 better than P.R. 1016, P.R. 1013, P.R. 1028 and B. 4362; P.R. 975 better than P.R. 1016, P.R. 1028 and P.R. 1013; B. 4362 better than P.R. 1016 and P.R. 1028. At the 5-percent level, P.R. 980 better than P.R. 975; B. 4362 better than P.R. 1013; P.R. 1013 better than P.R. 1016.

At the 1-percent level, P.R. 980 and P.R. 975 better than P.R. 1016, P.R. 1028 and B. 4362; P.R. 1013 and B. 4362 better than P.R. 1016. At the 5-percent level, P.R. 980 and P.R. 975 better than P.R. 1013.

- At the 1-percent level, all varieties better than P.R. 1016 and P.R. 1028.

5 At the 1-percent level, P.R. 980 and P.R. 975 better than P.R. 1028, P.R. 1016 and P.R. 1013; B. 4362 better than P.R. 1028 and P.R. 1016; P.R. 1013 better than P.R. 1028. At the 5-percent level, P.R. 980 and P.R. 975 better than B. 4362.

- At the 1-percent level, P.R. 980, P.R. 975 and P.R. 1013 better than P.R. 1028; P.R. 980 better than PR. 1016. At the 5-percent level, P.R. 975 and P.R. 1013 better than P.R. 1016.

7 At the 1-percent level, P.R. 975, P.R. 1013 and P.R. 980 better than P.R. 1016. At the 5-percent level, P.R. 975 and P.R. 1013 better than B. 4362; P.R. 1028 better than P.R. 1016.

${ }^{8}$ At the 1-percent level, P.R. 980, P.R. 975 and P.R. 1013 better than B. 4362 and P.R. 1016; P.R. 1028 better than B. 4362. At the 5-percent level, P.R. 980 and P.R. 975 better than P.R. 1028; P.R. 1028 better than B. 4362.

than B. 4362, while the latter was better than P.R. 1013. For the 18-month crop cycle, all varieties were superior at the 1-percent level to P.R. 1028 and P.R. 1016; P.R. 980, in addition, was superior to B. 4362; and P.R. 975 was superior to B. 4362 as far as tons of cane per acre per acre per month. At the 5-percent level, P.R. 975 and P.R. 980 were better than P.R. 1013; and P.R. 1016 was better than P.R. 1028. For the 24-month crop cycle, P.R. 
975, P.R. 980 and P.R. 1013 outyielded P.R. 1016 and B. 4362 at the 1-percent level, and P.R. 1028 at the 5-percent level. Variety P.R. 1028 outyielded P.R. 1016 at the 1-percent level.

In comparing the performance of these varieties at various ages it is evi-

TABLE 8.-Tons of cane per acre obtained from each crop for each of the three cropping cycles at Barceloneta

\begin{tabular}{|c|c|c|c|c|c|c|}
\hline \multirow{2}{*}{ Crop cycle } & \multicolumn{6}{|c|}{ Yields for indicated variety } \\
\hline & P.R. 1028 & P.R. 1016 & P.R. 1013 & P.R. 980 & P.R. 975 & B. 4362 \\
\hline 12-month & & & & & & \\
\hline Plant crop 1 & 73.9 & 62.9 & 84.4 & 79.0 & 68.6 & 71.1 \\
\hline First ratoon ${ }^{\circ}$ & 61.8 & 44.9 & 68.4 & 83.0 & 60.8 & 48.9 \\
\hline Second ratoon ${ }^{3}$ & 68.0 & 55.2 & 78.0 & 87.8 & 64.0 & 60.5 \\
\hline Third ratoon & 57.8 & 39.4 & 47.0 & 57.8 & 55.8 & 38.6 \\
\hline 18-month & & & & & & \\
\hline Plant crop 5 & 91.6 & 87.6 & 80.7 & 108.9 & 79.8 & 101.2 \\
\hline First ratoon 6 & 73.2 & 52.0 & 69.2 & 73.4 & 62.9 & 55.1 \\
\hline Second ratoon ${ }^{7}$ & 73.0 & 58.7 & 69.0 & 78.3 & 69.5 & 62.0 \\
\hline 24-month & & & & & & \\
\hline Plant crop 8 & 115.5 & 68.3 & 93.3 & 113.3 & 91.7 & 81.4 \\
\hline First ratoon" & 84.8 & 36.3 & 78.8 & 97.2 & 72.3 & 58.7 \\
\hline
\end{tabular}

${ }^{1}$ At the 1-percent level, P.R. 1013 better than P.R. 1016. At the 5-percent level, P.R. 1013 better than P.R. 975; P.R. 980 better than P.R. 1016.

2 At the 1-percent level, P.R. 980 better than P.R. 1016, B. 4362, P.R. 975 and P.R. 1028; P.R. 1013 better than P.R. 1016 and B. 4362; P.R. 1028 and P.R. 975 better than P.R. 1016. At the 5-percent level, P.R. 980 better than all other varieties; P.R. 1028 and P.R 975 better than B. 4362.

${ }^{3}$ At the 1-percent level, P.R. 980 better than P.R. 1016, B. 4362, P.R. 975 and P.R. 1028; P.R. 1013 better than P.R. 1016. At the 5-percent level, P.R. 1013 better than B. 4362 .

- At the 1-percent level, P.R. 1028, P.R. 980 and P.R. 975 better than B. 4362 and P.R. 1016.

No significant differences.

- No significant differences.

7 At the 5-percent level, P.R. 980 better than P.R. 1016.

${ }^{8}$ At the 1-percent level, P.R. 1028 and P.R. 980 better than P.R. 1016. At the 5-percent level, P.R. 1028 and P.R. 980 better than B. 4362.

9 At the 5-percent level, all varieties better than P.R. 1016; P.R. 980, P.R. 1028 and P.R. 1013 better than B. 4362 ; 980 better than P.R. 975.

dent that varieties P.R. 1028, P.R. 980, P.R. 975 and B. 4362 perform better as 12- and 18-month canes than as 24-month cane. The mean differences are highly significant. Varieties P.R. 1016 and P.R. 1013 performed better (1-percent level) at 12 months than at 24 months, but differences between 
TABLE 9.-Tons of cane per acre per month from each crop for each of three cropping cycles at Corozal

\begin{tabular}{|c|c|c|c|c|c|c|}
\hline \multirow{2}{*}{ Crop cycle } & \multicolumn{6}{|c|}{ Yields for indicated variety } \\
\hline & P.R. 1028 & P.R. 1016 & P.R. 1013 & P.R. 980 & P.R. 975 & B. 4362 \\
\hline 12-month & & & & & & \\
\hline Plant crop ${ }^{1}$ & 5.53 & 4.58 & 6.13 & 7.40 & 7.85 & 7.36 \\
\hline First ratoon ${ }^{2}$ & 3.33 & 2.93 & 3.55 & 4.88 & 4.43 & 4.14 \\
\hline Second ratoon & 3.94 & 3.43 & 4.31 & 5.04 & 5.00 & 4.18 \\
\hline 18-month & & & & & & \\
\hline Plant crop & 3.86 & 4.35 & 5.37 & 5.74 & 5.88 & 5.43 \\
\hline First ratoon ${ }^{6}$ & 3.04 & 3.21 & 3.66 & 4.20 & 4.08 & 3.75 \\
\hline Second ratoon" & 3.29 & 3.69 & 4.33 & 4.73 & 4.73 & 3.69 \\
\hline 24-month & & & & & & \\
\hline Plant crop & 2.52 & 1.95 & 2.81 & 2.66 & 2.83 & 2.35 \\
\hline First ratoon 8 & 2.24 & 1.89 & 2.65 & 2.93 & 2.79 & 1.55 \\
\hline
\end{tabular}

${ }^{1}$ At the 1-percent level, P.R. 975, P.R. 980 and B. 4362 better than P.R. 1016 and P.R. 1028; P.R. 975 better than P.R. 1013; P.R. 1013 better than P.R. 1016. At the 5-percent level, P.R. 980 and B. 4362 better than P.R. 1013.

At the 1-percent level, P.R. 980 better than P.R. 1016, P.R. 1028, P.R. 1013 and B. 4362; P.R. 975 better than P.R. 1016, P.R. 1028 and P.R. 1013; B. 4362 better than P.R. 1016 and P.R. 1028; P.R. 1013 better than P.R. 1016. At the 5-percent level, P.R. 980 better than P.R. 975; B. 4362 better than P.R. 1013.

${ }^{3}$ At the 1-percent level, P.R. 980 and P.R. 975, better than P.R. 1016, P.R. 1028 and B. 4362; P.R. 1013 and B. 4362 better than P.R. 1016. At the 5-percent level, P.R. 980 and P.R. 975 better than P.R. 1013.

- At the 1-percent level, all varieties better than P.R. 1016 and P.R. 1028.

' At the 1-percent level, P.R. 980 better than P.R. 1028, P.R. 1016 and P.R. 1013; P.R. 975 and B. 4362 better than P.R. 1028 and P.R. 1016; P.R. 1013 better than P.R. 1028. At the 6-percent level, P.R. 980 better than B. 4362 ; P.R. 975 better than P.R. 1013; P.R. 1013 better than P.R. 1016.

- At the 1-percent level, P.R. 980 and P.R. 975 better than P.R. 1028 and P.R. 1016; P.R. 1013 better than P.R. 1028. At the 5-percent level, P.R. 1013 better than P.R. 1016.

7 At the 1-percent level, P.R. 975, P.R. 1013 and P.R. 980 better than P.R. 1016. At the 5-percent level, P.R. 975 better than B. 4362; P.R. 1028 better than P.R. 1016.

${ }^{8}$ At the 1-percent level, P.R. 980 better than B. 4362, P.R. 1016 and P.R. 1028; P.R. 975 and P.R. 1013 better than B. 4362 and P.R. 1016; P.R. 1028 better than B. 4362. At the 5-percent level, P.R. 975 better than P.R. 1028.

mean yields at 12 and 18 months were highly significant in favor of variety P.R. 1013.

At Barceloneta, for the 12-month crop cycle, P.R. 980, P.R. 1013 and P.R. 1028 outyielded P.R. 1016 and B. 4362 ; P.R. 975 also outyielded P.R. 1016; P.R. 980 was superior to P.R. 975 and P.R. 1028; mean differences were highly significant. At the 5-percent level, P.R. 980 was better than 
P.R. 1013, which in turn was better than P.R. 975 that also ranked better than B. 4362. For the 18-month crop cycle, P.R. 980 proved to be superior at the 1-percent level than P.R. 1016. It was also better at the 5-percent level than P.R. 975. In addition, P.R. 980 was better than B. 4362 and P.R.

TABLE 10.-Tons of cane per acre per month from each crop for each of the three cropping cycles, Barceloneta

\begin{tabular}{|c|c|c|c|c|c|c|}
\hline \multirow{2}{*}{ Crop cycle } & \multicolumn{6}{|c|}{ Yields for indicated variety } \\
\hline & P.R. 1028 & P.R. 1016 & R.R. 1013 & P.R. 980 & P.R. 975 & B. 4362 \\
\hline \multicolumn{7}{|l|}{ 12-month } \\
\hline Plant crop & 6.16 & 5.24 & 7.03 & 6.58 & 5.72 & 5.93 \\
\hline First ratoon 2 & 5.15 & 3.74 & 5.70 & 6.92 & 6.07 & 4.08 \\
\hline Second ratoon & 5.67 & 4.60 & 6.50 & 7.32 & 5.33 & 5.04 \\
\hline Third ratoon & 4.82 & 3.28 & 3.92 & 4.82 & 4.65 & 3.22 \\
\hline \multicolumn{7}{|l|}{ 18-month } \\
\hline Plant crops & 5.09 & 4.87 & 4.48 & 6.05 & 4.43 & 5.63 \\
\hline First ratoon ${ }^{\circ}$ & 6.10 & 4.33 & 5.77 & 6.12 & 5.24 & 4.59 \\
\hline Second ratoon 7 & 6.08 & 4.89 & 5.75 & 6.53 & 5.79 & 5.17 \\
\hline \multicolumn{7}{|l|}{ 24-month } \\
\hline Plant crop ${ }^{8}$ & 4.81 & 2.85 & 3.89 & 4.72 & 3.82 & 3.39 \\
\hline First ratoon & 3.53 & 1.51 & 3.28 & 4.05 & 3.01 & 2.45 \\
\hline
\end{tabular}

${ }^{1}$ At the 1-percent level, P.R. 1013 better than P.R. 1016. At the 5-percent level, P.R. 1013 better than P.R. 975; P.R. 980 better than P.R. 1016.

2 At the 1-percent level, P.R. 980 better than P.R. 1016, B. 4362, P.R. 975 and P.R. 1028; P.R. 1013 better than P.R. 1016 and B. 4362; P.R. 1028 and P.R. 975 better than P.R. 1016. At the 5-percent level, P.R. 980 better than P.R. 1013; P.R. 1028 and P.R. 975 better than B. 4362 .

At the 1-percent level, P.R. 980 better than P.R. 1016, B. 4362, P.R. 975 and P.R. 1028; P.R. 1013 better than P.R. 1016. At the 5-percent level, P.R. 1013 better than B. 4362 .

At the 1-percent level, P.R. 1028, P.R. 980 and P.R. 975 better than B. 4362 and P.R. 1016.

No significant differences.

- No significant differences.

7 At the 5-percent level, P.R. 980 better than P.R. 1016 and B. 4362.

8 At the 1-percent level, P.R. 1028 and P.R. 980 better than P.R. 1016. At the 5-percent level, P.R. 1028 and P.R. 980 better than B. 4362.

- At the 1-percent level, P.R. 980 and P.R. 1028 better than P.R. 1016 and B. 4362; P.R. 1013 and P.R. 975 better than P.R. 1016. At the 5-percent level, P.R. 980 better than P.R. 975; P.R. 1013 better than B. 4362; B. 4362 better than P.R. 1016.

1028 was better than P.R. 1016 in terms of tons of cane per acre per month. Tables 2 and 3 also show that for the 24-month crop cycle, P.R. 980 and P.R. 1028 were superior to P.R. 1016 and B. 4362; P.R. 1013 and P.R. 975 were also superior to P.R. 1016; P.R. 980 was superior to P.R. 975. At the 
5-percent level, P.R. 980 outyielded P.R. 1013; P.R. 1028 outyielded P.R. 975; B. 4362 outyielded P.R. 1016. P. R. 1013 outyielded B. 4362 in terms of tons of cane per acre and per acre per month.

In general, all the varieties performed best at the shorter crop cycles, i.e., 12 and 18 months as compared to 24 months. Mean differences in terms

TABLE 11.-Sucrose percent cane obtained from each crop for each of three cropping cycles at Corozal

\begin{tabular}{|c|c|c|c|c|c|c|}
\hline \multirow{2}{*}{ Crop cycle } & \multicolumn{6}{|c|}{ Yields for indicated variety } \\
\hline & P.R. 1028 & P.R. 1016 & P.R. 1013 & P.R. 980 & P.R. 975 & B. 4362 \\
\hline 12-month & & & & & & \\
\hline Plant crop ${ }^{2}$ & 12.07 & 12.30 & 11.80 & 10.73 & 12.31 & 12.72 \\
\hline First ratoon ${ }^{2}$ & 12.67 & 13.81 & 12.68 & 11.94 & 12.85 & 13.70 \\
\hline $\begin{array}{l}\text { Second ratoon } \\
\text { 18-month }\end{array}$ & 13.04 & 13.10 & 13.71 & 12.45 & 12.67 & 13.27 \\
\hline Plant crop 4 & 11.94 & 13.03 & 12.19 & 11.38 & 12.53 & 12.96 \\
\hline First ratoon 5 & 12.70 & 13.79 & 12.81 & 11.88 & 13.20 & 13.66 \\
\hline Second ratoon ${ }^{6}$ & 13.05 & 12.71 & 13.05 & 12.95 & 13.65 & 12.59 \\
\hline $\begin{array}{l}\text { 24-month } \\
\text { Plant cron? }\end{array}$ & 12.74 & 13.46 & & & & \\
\hline $\begin{array}{l}\text { Plant crop } \\
\text { First ratoon }\end{array}$ & 12.65 & $\begin{array}{l}10.40 \\
13.67\end{array}$ & $\begin{array}{l}13.39 \\
13.20\end{array}$ & $\begin{array}{l}12.10 \\
12.74\end{array}$ & $\begin{array}{l}13.15 \\
13.76\end{array}$ & $\begin{array}{l}13.10 \\
13.19\end{array}$ \\
\hline
\end{tabular}

1 At the 1-percent level, B. 4362, P.R. 975, P.R. 1016 and P.R. 1028 better than P.R. 980. At the 5-percent level, P.R. 1013 better than P.R. 980.

2 At the 1-percent level, P.R. 1016 better than P.R. 980, P.R. 1028 and P.R. 1013; B. 4362 better than P.R. 980. At the 5-percent level, P.R. 1016 better than P.R. 975; B. 4362 better than P.R. 1028, P.R. 1013 and P.R. 975.

3 No significant differences.

- At the 1-percent level, P.R. 1016 and B. 4362 better than P.R. 980. At the 5-percent level, P.R. 1016 and B. 4362 better than P.R. 1028; P.R. 975 better than P.R. 980.

B At the 1-percent level, P.R. 1016, B. 4362 and P.R. 975 better than P.R. 980. At the 5-percent level, P.R. 1016 better than P.R. 1028 and P.R. 1013; B. 4362 better than P.R. 1028; P.R. 1013 better than P.R. 980.

- No significant differences.

I At the 1-percent level, P.R. 1016, P.R. 1013, P.R. 975 and B. 4362 better than P.R. 980 .

At the 1-percent level, P.R. 975 and P.R. 1016 better than all other varieties.

of tons of cane per acre per month were highly significant in most cases in favor of 12- and 18-month canes. This also was the case, in general terms, when tons of cane per acre was considered as a criterion. Varieties P.R. 975 and P.R. 1013 produced significantly higher yields of cane per acre at 12 months when compared to its performance at 18 months. Evidently, these varieties clearly are short growing-season canes. 
Table 4 presents performance data of the varieties tested in terms of sucrose percent cane. At Corozal, for the 12-month cycle, all varieties were superior at the 1-percent level to P.R. 980. At the 5-percent level, B. 4362 was better than P.R. 1028 and P.R. 975. For the 18-month cycle, P.R. 1016,

TABLE 12.-Sucrose percent cane obtained from each crop for each of the three cropping cycles at Barceloneta

\begin{tabular}{|c|c|c|c|c|c|c|}
\hline \multirow{2}{*}{ Crop cycle } & \multicolumn{6}{|c|}{ Yields for indicated variety } \\
\hline & P.R. 1028 & P.R. 1016 & P.R. 1013 & P.R. 980 & P.R. 975 & B. 4362 \\
\hline \multicolumn{7}{|l|}{ 12-month } \\
\hline Plant crop ${ }^{1}$ & 9.70 & 9.84 & 9.52 & 9.12 & 9.70 & 10.53 \\
\hline First ratoon 2 & 11.44 & 12.01 & 11.67 & 10.45 & 10.83 & 11.68 \\
\hline Second ratoon ${ }^{3}$ & 11.45 & 11.45 & 10.87 & 9.96 & 11.59 & 12.74 \\
\hline Third ratoon & 11.89 & 11.38 & 13.12 & 11.50 & 12.47 & 12.50 \\
\hline \multicolumn{7}{|l|}{ 18-month } \\
\hline Plant crops & 10.90 & 10.89 & 10.33 & 8.86 & 12.15 & 11.54 \\
\hline First ratoon 6 & 12.14 & 11.32 & 11.92 & 10.25 & 12.02 & 12.54 \\
\hline Second ratoon? & 12.24 & 12.16 & 11.46 & 10.16 & 11.83 & 13.24 \\
\hline \multicolumn{7}{|l|}{ 24-month } \\
\hline Plant crop 8 & 12.33 & 13.26 & 12.85 & 10.29 & 12.28 & 12.86 \\
\hline First ratoon ${ }^{\circ}$ & 12.28 & 12.48 & 12.24 & 11.50 & 12.65 & 13.02 \\
\hline
\end{tabular}

1 No significant differences.

2 At the 5-percent level, P.R. 1016, B. 4362 and P.R. 1013 better than P.R. 980; P.R. 1016 better than P.R. 975.

At the 1-percent level, B. 4362, P.R. 975, P.R. 1028 and P.R. 1016 better than P.R. 980; B. 4362 better than P.R. 1013. At the 5-percent level, B. 4362 better than P.R. 1016, P.R. 1028 and P.R. 975.

- At the 1-percent level, P.R. 1013 better than P.R. 1028, P.R. 980 and P.R. 1016; B. 4362 and P.R. 975 better than P.R. 980 and P.R. 1016.

5 At the 1-percent level, P.R. 975, P.R. 1028, B. 4362 and P.R. 1016 better than P.R. 980. At the 5-percent level, all varieties better than P.R. 980; P.R. 975 better than P.R. 1013.

- At the 1-percent level, B. 4362 better than P.R. 980. At the 5-percent level, P.R. 1028, P.R. 975 and P.R. 1013 better than P.R. 980.

7 At the 1-percent level, all varieties better than P.R. 980; B. 4362 also better than P.R. 1013 and P.R. 975. At the 5-percent level, B. 4362 better than P.R. 1016 and P.R. 1028.

At the 1-percent level, all varieties better than P.R. 980. At the 5-percent level, P.R. 1016 better than P.R. 975 and P.R. 1028.

- At the 5-percent level, all varieties better than P.R. 980.

P.R. 975 and B. 4362 were superior to P.R. 980; P.R. 1013 was also better, at the 5-percent level, than P.R. 980. At this same level of significance, P.R. 1016 was better than P.R. 1028. The situation is similar in the case of 24month cane with P.R. 1016 and P.R. 975 superior to P.R. 980 and P.R. 
TABLE 13.-Tons of sugar per acre oblained from each crop for each of three cropping cycles at Corozal

\begin{tabular}{|c|c|c|c|c|c|c|}
\hline \multirow{2}{*}{ Crop cycle } & \multicolumn{6}{|c|}{ Yields for indicated variety } \\
\hline & P.R. 1028 & P.R. 1016 & P.R. 1013 & P.R. 980 & P.R. 975 & B.4362 \\
\hline \multicolumn{7}{|l|}{ 12-month } \\
\hline Plant crop 1 & 8.0 & 6.8 & 8.7 & 9.5 & 11.6 & 10.5 \\
\hline First ratoon? & 5.0 & 4.9 & 5.4 & 7.0 & 6.8 & 6.8 \\
\hline Second ratoon 8 & 6.2 & 5.4 & 7.1 & 7.5 & 7.6 & 6.7 \\
\hline \multicolumn{7}{|l|}{ 18-month } \\
\hline Plant crops & 8.3 & 10.0 & 11.8 & 11.8 & 13.3 & 12.7 \\
\hline First ratoon ${ }^{5}$ & 4.6 & 5.3 & 5.6 & 6.0 & 6.5 & 6.2 \\
\hline Second ratoon ${ }^{6}$ & 5.2 & 5.6 & 6.8 & 7.4 & 7.4 & 5.6 \\
\hline \multicolumn{7}{|l|}{ 24-month } \\
\hline Plant crop? & 7.7 & 6.3 & 9.0 & 7.7 & 8.9 & 7.4 \\
\hline First ratoon ${ }^{8}$ & 6.8 & 6.2 & 8.4 & 8.9 & 9.2 & 4.9 \\
\hline
\end{tabular}

1 At the 1-percent level, P.R. 975 better than P.R. 1016, P.R. 1028 and P.R. 1013; B. 4362 better than P.R. 1016 and P.R. 1028; P.R. 980 better than P.R. 1016. At the 5-percent level, P.R. 975 better than P.R. 980; B. 4362 better than P.R. 1013; P.R. 1013 better than P.R. 1016.

At the 5-percent level, P.R. 980, P.R. 975 and B. 4362 better than P.R. 1016, P.R. 1028 and P.R. 1013.

At the 1-percent level, P.R. 975 and P.R. 980 better than P.R. 1016 and P.R. 1028; P.R. 1013 better than P.R. 1016. At the 5-percent level, B. 4362 better than P.R. 1016.

- At the 1-percent level, P.R. 975, B. 4362, P.R. 980 and P.R. 1013 better than P.R. 1028; P.R. 975 better than P.R. 1016. At the 5-percent level, B. 4362 better than P.R. 1016.

5 At the 1-percent level, P.R. 975 better than P.R. 1028 and P.R. 1016; B. 4362 and P.R. 980 better than P.R. 1028. At the 5-percent level, P.R. 975 better than P.R. 1013; B. 4362 better than P.R. 1016; P.R. 1013 better than P.R. 1028.

- At the 1-percent level, P.R. 980 and P.R. 975 better than P.R. 1028, B. 4362 and P.R. 1016. At the 5-percent level, P.R. 1013 better than P.R. 1028, B. 4362 and P.R. 1016.

7 At the 1-percent level, P.R. 1013 and P.R. 975 better than P.R. 1016. At the 5-percent level, P.R. 1013 and P.R. 975 better than B. 4362.

${ }^{8}$ At the 1-percent level, P.R. 975 and P.R. 980 better than B. 4362, P.R. 1016 and P.R. 1028; P.R. 1013 better than B. 4362 and P.R. 1016. At the 5-percent level, P.R. 1013 better than P.R. 1028; P.R. 1028 better than B. 4362.

1028; P.R. 1013 and B. 4362 superior to P.R. 980; and P.R. 1013 better than P.R. 1028. At Barceloneta, again, all varieties produced higher sucrose yields than P.R. 980 for the 12-month cycle; the differences were highly significant. At the 5-percent level, B. 4362 also produced higher yields than the other varieties. The situation is identical as far as P.R. 980 is concerned for the 18-month crop cycle; B. 4362 was superior again to P.R. 1013 and 
better than P.R. 1016. At 24 months all varieties produced higher yields than P.R. 980; the differences were highly significant. At the 5-percent level B. 4362 produced higher yields than P.R. 1028.

Most verieties performed better, in general, in terms of sucrose percent cane, at both locations at 24 months than at either 12 or 18 months, except

TABLE 14.-Tons of sugar per acre obtained from each crop for each of the three cropping cycles at Barceloneta

\begin{tabular}{|c|c|c|c|c|c|c|}
\hline \multirow{2}{*}{ Crop cycle } & \multicolumn{6}{|c|}{ Yield for indicated variety } \\
\hline & P.R. 1028 & P.R. 1016 & P.R. 1013 & P.R. 980 & P.R. 975 & B. 4362 \\
\hline 12-month & & & & & & \\
\hline Plant crop ${ }^{2}$ & 7.2 & 6.3 & 8.0 & 7.2 & 6.5 & 7.5 \\
\hline First ratoon ${ }^{2}$ & 7.1 & 5.4 & 8.0 & 8.7 & 6.6 & 5.7 \\
\hline Second ratoon & 7.9 & 6.4 & 8.5 & 8.9 & 7.5 & 7.8 \\
\hline Third ratoon & 6.9 & 4.5 & 6.1 & 6.7 & 6.9 & 4.8 \\
\hline \multicolumn{7}{|l|}{ 18-month } \\
\hline Plant crops & 9.8 & 9.7 & 8.3 & 9.6 & 9.7 & 11.4 \\
\hline First ratoon" & 8.9 & 6.0 & 8.4 & 7.6 & 7.6 & 6.9 \\
\hline Second ratoon ${ }^{7}$ & 9.0 & 7.1 & 7.9 & 8.0 & 8.2 & 8.2 \\
\hline \multicolumn{7}{|l|}{ 24-month } \\
\hline Plant crops & 14.3 & 9.1 & 12.0 & 11.7 & 11.3 & 10.5 \\
\hline First ratoon & 10.5 & 4.5 & 9.6 & 11.2 & 9.2 & 7.7 \\
\hline
\end{tabular}

1 At the 5-percent level, P.R. 1013 better than P.R. 1016.

2 At the 1-percent level, P.R. 980 better than P.R. 1016 and B. 4362; P.R. 1013 better than P.R. 1016. At the 5-percent level, P.R. 980 better than P.R: 975; P.R. 1013 better than B. 4362; and P.R. 1028 better than P.R. 1016.

s At the 5-percent level, P.R. 980 and P.R. 1013 better than P.R. 1016.

- At the 1-percent level, P.R. 975 and P.R. 1028 better than P.R. 1016 and B. 4362; P.R. 980 better than P.R. 1016. At the 5-percent level, P.R. 980 better than B. 4362; P.R. 1013 better than P.R. 1016 and B. 4362.

- No significant differences.

- At the 5-percent level, P.R. 1028 better than P.R. 1016.

7 No significant differences.

At the 1-percent level, P.R. 1028 better than P.R. 1016. At the 5-percent level, P.R. 1028 better than B. 4362.

- At the 1-percent level, P.R. 980, P.R. 1028, P.R. 1013 and P.R. 975 better than P.R. 1016; P.R. 980 better than B. 4362 . At the 5-percent level, B. 4362 better than P.R. 1016; P.R. 1028 better than B. 4362.

at Corozal where P.R. 1028 and B. 4362 performed almost identically in all three cycles.

The performance of the different varieties as compared to each other within each crop cycle and each one for each cropping cycle, in terms of total sugar production per acre and tons of sugar per acre per month, is shown in tables 5 and 6. 
At Corozal, for the 12-month crop cycle, P.R. 980, P.R. 975 and B. 4362 performed better than P.R. 1016, P.R. 1028 and P.R. 1013; P.R. 1013 also was better than P.R. 1016. These differences were highly significant. At the

TABLE 15.-Tons of sugar per acre per month oblained from each crop for each of three cropping cycles at Corozal

\begin{tabular}{l|r|r|r|r|r|r}
\hline \multirow{2}{*}{ Crop cycle } & \multicolumn{5}{|c}{ Tons of sugar per acre per month for indicated varieties } \\
\cline { 2 - 7 } & P.R. 1028 & P.R. 1016 & P.R. 1013 & P.R. 980 & P.R. 975 & B. 4362 \\
\hline 12-month & & & & & & \\
Plant crop1 & 0.667 & 0.567 & 0.717 & 0.791 & 0.967 & 0.933 \\
First ratoon & .417 & .408 & .450 & .583 & .567 & .558 \\
Second ratoon & .517 & .450 & .591 & .625 & .633 & .550 \\
18-month & & & & & & \\
Plant crop4 & .461 & .850 & .656 & .656 & .733 & .706 \\
First ratoon & .383 & .442 & .467 & .500 & .542 & .518 \\
Second ratoon & .425 & .467 & .567 & .616 & .617 & .467 \\
24-month & & & & & & \\
Plant crop & .320 & .262 & .375 & .320 & .371 & .308 \\
First ratoon & .283 & .258 & .350 & .371 & .383 & .204 \\
\hline
\end{tabular}

1 At the 1-percent level, P.R. 975 and B. 4362 better than P.R. 1016, P.R. 1028 and P.R. 1013; P.R. 980 better than P.R. 1016. At the 5-percent level, P.R. 975 and B. 4362 better than P.R. 980; P.R. 1013 better than P.R. 1016.

2 At the 1-percent level, P.R. 980, P.R. 975 and B. 4362 better than P.R. 1016, P.R 1028 and P.R. 1013.

3 At the 1-percent level, P.R. 975 better than P.R. 1016 and P.R. 1028; P.R. 980 and P.R. 1013 better than P.R. 1016. At the 5-percent level, B. 4362 better than P.R. 1016.

- At the 1-percent level, P.R. 1016 better than P.R. 1028, P.R. 1013 and B. 4362; P.R. 975, B. 4362, P.R. 1013 and P.R. 980 better than P.R. 1028. At the 5-percent level, P.R. 1016 better than P.R. 975.

B At the 1-percent level, P.R. 975 better than P.R. 1028 and P.R. 1016; B. 4362 and P.R. 980 better than P.R. 1028. At the 5-percent level, P.R. 975 better than P.R. 1013; B. 4362 better than P.R. 1016; P.R. 1013 better than P.R. 1028.

${ }^{6}$ At the 1-percent level, P.R. 975 and P.R. 980 better than P.R. 1028 and P.R. 1016; P.R. 1013 better than P.R. 1028. At the 5-percent level, P.R. 1013 better than P.R. 1016.

7 At the 1-percent level, P.R. 1013 and P.R. 975 better than P.R. 1016. At the 5-percent level, P.R. 1013 and P.R. 975 better than B. 4362.

${ }^{8}$ At the 1-percent level, P.R. 975 and P.R. 980 better than B. 4362, P.R. 1016 and P.R. 1028; P.R. 1013 better than B. 4362 and P.R. 1016. At the 5-percent level, P.R. 1013 better than P.R. 1028; P.R. 1028 better than B. 4362.

5-percent level, P.R. 1028 was better than P.R. 1016. For the 18-month crop cycle, P.R. 975, P.R. 980, B. 4362 and P.R. 1013 proved superior to P.R. 1028; P.R. 980, P.R. 975 and B. 4362 were superior to P.R. 1016. At the 5- 
percent level, P.R. 980 and P.R. 975 were better than B. 4362 and P.R. 1013; P.R. 1016 was better than P.R. 1028. For the 24-month cycle, P.R. 975, P.R. 1013 and P.R. 980 were superior to B. 4362 and P.R. 1016; P.R. 975 and P.R. 1013 were superior to P.R. 1028. At the 5-percent level, P.R. 980 was better than P.R. 1028; this in turn was better than B. 4362 .

TABLE 16.-Tons of sugar per acre per month obtained from each crop for each of the three cropping cycles at Barceloneta

\begin{tabular}{l|r|r|r|r|r|r}
\hline \multirow{2}{*}{ Crop cycle } & \multicolumn{5}{|c}{ Yield for indicated varieties } \\
\cline { 2 - 7 } & P.R. 1028 & P.R. 1016 & P.R. 1013 & P.R. 980 & P.R. 975 & B. 4362 \\
\hline 12-month & & & & & & \\
Plant crop' & 0.600 & 0.525 & 0.667 & 0.600 & 0.542 & 0.625 \\
First ratoon' & .591 & .450 & .667 & .725 & .550 & .475 \\
Second ratoon $^{8}$ & .658 & .533 & .708 & .742 & .625 & .650 \\
Third ratoon & .575 & .375 & .508 & .558 & .575 & .400 \\
18-month & & & & & & \\
Plant crop & .544 & .539 & .461 & .533 & .539 & .633 \\
First ratoon & .742 & .500 & .700 & .633 & .633 & .575 \\
Second ratoon & .750 & .592 & .658 & .667 & .683 & .683 \\
24-month & .596 & .380 & .500 & .488 & .471 & .438 \\
Plant crop & .438 & .188 & .400 & .467 & .383 & .321 \\
First ratoon & .438 &
\end{tabular}

1 At the 5-percent level, P.R. 1013 better than P.R. 1016.

2 At the 1-percent level, P.R. 980 and P.R. 1013 better than P.R. 1016 and B. 4362. At the 6-percent level, P.R. 980 better than P.R. 975; P.R. 1028 better than P.R. 1016.

'At the 5-percent level, P.R. 980 and P.R. 1013 better than P.R. 1016.

- At the 1-percent level, P.R. 1028 and P.R. 975 better than P.R. 1016 and B. 4362; P.R. 980 better than P.R. 1016. At the 5-percent level, P.R. 980 better than B. 4362; P.R. 1013 better than P.R. 1016.

No significant differences.

- At the 5-percent level, P.R. 1028 better than P.R. 1016.

7 No significant differences.

${ }^{8}$ At the 1-percent level, P.R. 1028 better than P.R. 1016. At the 5-percent level, P.R. 1028 better than B. 4362.

- At the 1-percent level, all varieties better than P.R. 1016. At the 5-percent level, P.R. 1028 and P.R. 980 better than B. 4362.

Yields of sugar were higher in general for all varieties at the 1-percent level for 12- and 18-month cane as compared to the longest cycle. Varieties P.R. 1016 and P.R. 1013 produced higher yields at 18 months than at 12, the differences being highly significant.

At Barceloneta, for the 12-month cycle, P.R. 980 and P.R. 1013 produced more total sugar per acre and more sugar per acre per month than P.R. 1016 
and B. 4362; P.R. 1028 and P.R. 975 also produced more than P.R. 1016. The differences were highly significant. At the 5-percent level, P.R. 980 was better than P.R. 975; P.R. 1028 was better than B. 4362. In addition, B. 4362 produced more sugar per acre per month than P.R. 1016. For the 18month cycle, no significant differences were measured between varieties in terms of tons of sugar per acre and per acre per month. As to tons of sugar per acre per month, the following differences were measured: At the 1-percent level, P.R. 1028 was better than all other varieties; B. 4362 was better than P.R. 1016, P.R. 1013 and P.R. 980; P.R. 975, P.R. 980 and P.R. 1013 were better than P.R. 1016. Also, at the 5-percent level, B. 4362 was better than P.R. 975. In the 24-month cycle, P.R. 1028, P.R. 980, P.R. 1013 and P.R. 975 were superior to P.R. 1016; P.R. 1028 was also superior to B. 4362. At the 5-percent level, B. 4362 in turn was better than P.R. 1016 and P.R. 980 was better than B. 4362 .

All varieties considered, 12 -month canes performed better in general than 24-month canes. P.R. 1016 and B. 4362 were better at 18 than at 24 months, whereas P.R. 1013 and P.R. 980 were better at 12 months than at 18. In terms of tons of sugar per acre per month, P.R. 1028 was better, at the 1percent level, at 18 months than at 24 . On this same basis all other varieties performed better at both 12 and 18 months than at 24 .

Detailed data for each crop year for each cropping cycle are given in tables 7 through 16. Footnotes at the end of each of these explain differences obtained upon statistical examination of the data. These differences are not discussed in the text but will be of interest to scientists and others interested in sugarcane production.

The results of these experiments show that currently available varieties of sugarcane, grown in typical soils under the prevailing management practices of Puerto Rico, are more efficient producers of sugar in 12-month and 18. month cropping cycles than in a cropping cycle of 24 months. The data shows that more cane tonnage and more total sugar per acre is produced by these varieties during shorter cropping cycles than during a longer, 24month cycle.

Varieties of sugarcane now available in Puerto Rico ripen early. Apparently they go into senescence prior to 24 months of age. If a 24-month cropping cycle is to be adopted in Puerto Rico, late-maturing varieties and more suitable management practices would seem essential.

It is time, obviously, to reorient the sugarcane breeding programs of Puerto Rico to fill the need for varieties of sugarcane adapted to longer cropping cycles. Such varieties might well lead to higher unit yields and to higher net farm income.

$\mathrm{Capo}^{3}$ demonstrated that harvesting P.R. variety 980 at 12 months de-

- Personal communication, May, 1969. 
prives the crop of the most efficient and probably least expensive period of sugar production, a period which may continue for 14 months or more in the humid north coast. The situation stated simply is this: The greatest proportion of synthesized sugar can be stored in cane only after the rate of stalk elongation decreases and the main stalks have developed fully (1).

The possibility of growing cane for longer cycles under Puerto Rican conditions deserves careful examination.

\section{SUMMARY}

The data presented in this paper are from field experiments conducted at Corozal and Barceloneta following a split plot design where sugarcane cropping cycles or age at harvest (12-, 18-, and 24-month) were the main plots and varieties were the subplots. The varieties studied were:P.R. 1028, P.R. 1016, P.R. 1013, P.R. 980, P.R. 975 and B. 4362. Six replications were used. Statistical analyses of the data revealed that under the conditions prevailing in Puerto Rico, with the sugarcane varieties now available, and under typical current soil and crop management practices, 12- and 18-month canes are more efficient sugar producers than 24-month cane. More cane tonnage and more total sugar per acre per month were obtained during the short cycles than during the 24-month cycle.

\section{RESUMEN}

En este trabajo se presentan los datos obtenidos de dos experimentos de campo establecidos uno en Corozal y el otro en Barceloneta. En ambos, se utilizó el diseño de parcelas divididas (split plot design) en el que los ciclos de cosecha, o sea la edad de la caña al cosecharse (12, 18 y 24 meses), comprendían las parcelas principales, las cuales a la vez se subdividieron para acomodar seis variedades de caña de azúcar. Se estudió el comportamiento de las siguientes variedades: P.R. 1028, P.R. 1016, P.R. 1013, P.R. 980, P.R. 975 y B. 4362. Cada tratamiento se replicó seis veces. Los estudios estadísticos de los datos obtenidos revelaron que, bajo las condiciones prevalecientes en las áreas donde se llevaron a cabo los experimentos o áreas similares en Puerto Rico, estando en uso las variedades de caña disponibles en la actualidad y considerando los métodos típicos del manejo de los suelos y cosechas en uso corriente, las cañas cosechadas a los 12 y a los 18 meses de sembradas producen más azúcar que las que se cosechan a los 24 meses. También los datos revelan que se puede obtener más tonelaje de caña por cuerda y más azúcar total por cuerda al mes cuando se adoptan los ciclos de cosechas de 12 y 18 meses que cuando el ciclo es de 24 meses.

\section{LITERATURE CITED}

1. Alers-Alers, S., A study on growth rate and sucrose content of three sugarcane varieties as indices of their maturity. A thesis submitted in partial fulfillment 
of the requirements for the degree of Master in Science, Univ. P.R., Mayagüez Campus, May 1968.

2. Ewart, G. Y., Sugarcane crop age based on two philosophies. Paper presented at the 13th Congress of the I.S.S.C.T., Taiwan, 1968.

3. Lugo-López, M. A., and Capó, B. G., The effect of elevation and the sucrose content of sugarcane, J. Agr. Univ. P.R., 88 (3): 128-31, 1954.

4. - The effect of weather and climate on the sucrose content of sugarcane, $J$. Agr. Univ. P.R., 88 (4): 149, 1954. 